\title{
Research on Processing Technology of Calcined Kaolin Powder Using a Fluidized Bed Jet Mill at Different Temperatures
}

\author{
Cui-Ping YAN ${ }^{1, a}$, Ming-Xing ZHANG ${ }^{2, b, *}$ \\ ${ }^{1,2}$ School of Environment and Resource, Southwest University of Science and Technology, \\ Mianyang, Sichuan, 621010, China \\ ayancuiping@swust.edu.cn, ${ }^{\mathrm{b}}$ zhangmingxing@swust.edu.cn \\ ${ }^{*}$ Corresponding author
}

Keywords: Jet mill, Calcined kaolin powder, High temperature, Grinding kinetic energy, Particle size.

\begin{abstract}
The calcined kaolin powder was obtained using a fluidized bed jet mill at the temperatures $17^{\circ} \mathrm{C}$ and $280^{\circ} \mathrm{C}$. The theoretical arithmetic, numerical simulation and experiment were used to compare and discuss the results at the two temperatures. The particle size $\mathrm{D}_{50}=2.401 \mu \mathrm{m}$ 与 $\mathrm{D}_{50}=2.003 \mu \mathrm{m}$ of kaolin powder was obtained. The theoretical arithmetic shows that the outlet velocity of the nozzle at the temperature $280^{\circ} \mathrm{C}$ is higher $(38 \%)$ than that at the temperature $17^{\circ} \mathrm{C}$. The grinding kinetic energy of the jet mill at the temperature $280^{\circ} \mathrm{C}$ is twice as that at the temperature $17^{\circ} \mathrm{C}$. The numerical simulation of grinding cavity at the temperatures $17^{\circ} \mathrm{C}$ and $280^{\circ} \mathrm{C}$ shows that nozzle axial velocity is $513 \mathrm{~m} / \mathrm{s}$ at the temperature $17^{\circ} \mathrm{C}$ and nozzle axial velocity is $712 \mathrm{~m} / \mathrm{s}$ at the temperature $280^{\circ} \mathrm{C}$. Therefore, the grinding particle size at the temperature $280^{\circ} \mathrm{C}$ is smaller than that at the temperature $17^{\circ} \mathrm{C}$. The yields of calcined kaolin powder and energy consumption of jet mill are obtained through the experiment. The yield of calcined kaolin powder at the temperature $280^{\circ} \mathrm{C}$ is higher $(14 \%)$ than that at the temperature $17^{\circ} \mathrm{C}$. The energy consumption of air jet mill at the temperature $280^{\circ} \mathrm{C}$ is higher $(30 \%)$ than that at the temperature $17^{\circ} \mathrm{C}$. The results show that the calcined kaolin powder at the temperature $280^{\circ} \mathrm{C}$ is beneficial to grinding materials with the smaller particle size and higher yield than that at the temperature $17^{\circ} \mathrm{C}$. Otherwise, the energy consumption of jet mill increase from the temperature $17^{\circ} \mathrm{C}$ to $280^{\circ} \mathrm{C}$.
\end{abstract}

\section{Introduction}

The kaolin powder has been widely used in the fields of papermaking, ceramics, plastics, coating, etc. [1-7]. In industry applications, the different grades of kaolin powder were classified based on fineness and whiteness. The fineness of kaolin used for the senior painting was lower than $2 \mu \mathrm{m}$ [8]. Recently, the ultrafine kaolin has gradually used in the new materials of refractory castable, 4A zeolite and carbon-white, etc. [9-10]. The prepared kaolin was obtained from mechanical method. The prepared kaolin has the characteristics of fine size and high specific area [11-12]. The Chinese processing technic for grinding kaolin has a distance to the national level [13]. However, the grinding method has obtained a notable progress in China. Ding et al. experiment showed that the $90 \%$ particle size of calcined coal kaolin clay was lower than $2 \mu \mathrm{m}$ using a wet grinding process [14]. Zhang et al. obtained that the mean particle size of calcined kaolin was lower than $4 \mu \mathrm{m}$ using a mechanical kinetic energy mill [15].

However, the purity of kaolin has a great influence on its application. The Fluidized bed jet mill is suitable for grinding the kaolin. The jet mill has no pollution on the kaolin in the grinding process. The qualified size distribution of the kaolin can be obtained using jet mill [16]. The fluidized bed jet mill uses the compressed air as the grinding energy. The compressed air goes through the supersonic nozzle and into grinding chamber. Then, the compressed air induces the kaolin particles to grind. The gas with the high temperature has a higher dynamic energy than the gas with normal temperature [17]. When the compressed air is heated, the grinding process of kaolin particles are carried at the high temperature. The kaolin particles should have fine particle size using the same classifier and the yield production of kaolin powder increases. 
The 2-3 mm size distribution of kaolin was chosen as the raw material in this experiment. The fluidized bed jet mill with three nozzles was used to grind the kaolin at the temperature $17^{\circ} \mathrm{C}$ and $280^{\circ} \mathrm{C}$. The three aspects of theoretical arithmetic, numeric simulation and experiment were used to compare and discuss the kaolin particle size, yields, energy consumption and grinding kinetic energy. This can provide an environment-friendly way that prepares the high quality and high-yield kaolin powder.

\section{Experimental Apparatus and Parameters}

\section{Raw Materials}

The calcined kaolin was used in this experiment. The kaolin was obtained from the Guizhou. The Moh's hardness was 7-8. The particle size was 2-3 mm. The main chemical components were as follows using the XRF: $\omega(\mathrm{SiO} 2)=59.29 \%, \quad \omega(\mathrm{Al} 2 \mathrm{O} 3)=19.44 \%, \quad \omega(\mathrm{Fe} 2 \mathrm{O} 3)=14.14 \%$, $\omega(\mathrm{CeO} 2)=2.15 \%, \omega(\mathrm{TiO} 2)=1.98 \%, \omega(\mathrm{K} 2 \mathrm{O})=1.27 \%$.

\section{Experimental Apparatus}

The flow sheet is shown in Fig.1. The main apparatus and parameters: LNJH-60A type fluidized bed jet mill (Designed by Mianyang, Liuneng, Powder Equipment, Co., Ltd.), LNJ-36A type classifier (Power of motor is $4 \mathrm{Kw}$, Transmission ratio is 1.5:1), Y4-73 type induced fan (Power of motor is $15 \mathrm{Kw}$, The maximum airflow is $1400 \mathrm{~m}^{3} / \mathrm{h}$ ), OG-150W type air compressor (Power is 37 $\mathrm{Kw})$. The 27 bags are installed in a filter. The dimensions of bag are $\varphi 120 \times 1500 \mathrm{~mm}$ and the filtration area is $15 \mathrm{~m}^{2}$. The filter medium with the surface treatment can resistance to $300^{\circ} \mathrm{C}$. Three nozzles are installed in the fluidized bed jet mill. The nozzle diameter is $5.8 \mathrm{~mm}$ and the Mach number is 1.98. The particle size of kaolin is measured using a laser particle size analyzer (Beckman Kurt LS13-320 type).

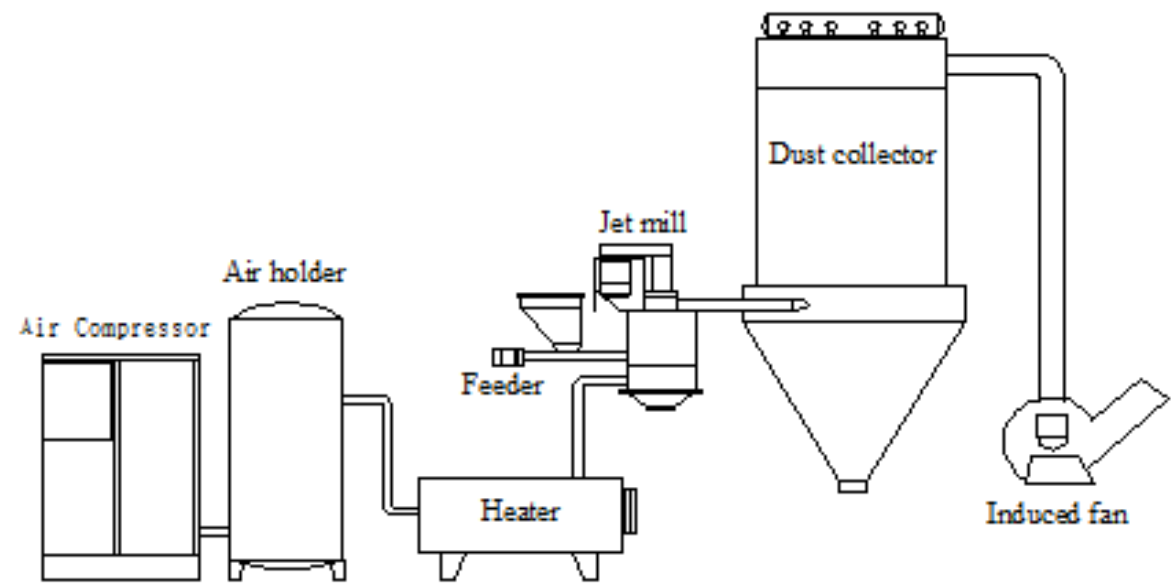

Fig.1 Flow sheet

\section{Experimental Process}

The fluidized bed jet mill is used to prepare the kaolin powder in this experiment. The compressed pressure $(0.76 \mathrm{MPa})$ can be obtained using an air compressor. The compressed air goes through the supersonic nozzles and is used to induce the kaolin particles to grind. In order to investigate the grinding process under the different temperatures, the compressed air is heated using a heater. The temperatures of the compressed air are controlled at the $17^{\circ} \mathrm{C}$ and $280^{\circ} \mathrm{C}$. The $2 \sim 3 \mathrm{~mm}$ raw materials of kaolin go into grinding chamber using a screw feeding machine. The kaolin particles are grinded in the grinding chamber. The total system has a negative condition using an induced fan. The grinded particles go into classification section with the high-speed airflow. The qualified kaolin particles go into the turbo classifier and then are collected in a filter. The coarse kaolin particles are separated from turbo classifier and go into grinding chamber. The coarse kaolin 
particles grind again in the chamber. The classification frequency is set to $38 \mathrm{~Hz}$. The current values and kaolin yields an hour are recorded in the experiment. The particle size of kaolin is measured using a laser particle size analyzer.

\section{Results and Discussions}

\section{Theoretical Arithmetic}

Outlet Velocity of Nozzles. The supersonic nozzles are used in this experiment. Mach number is 1.98. The airflow is assumed as adiabatic stability. The outlet velocity $u *$ of nozzle at the temperature $17^{\circ} \mathrm{C}$ and $280^{\circ} \mathrm{C}$ are calculated as follow (1) [18]:

$$
u_{*}=\sqrt{\frac{2 k}{k-1} R T_{1}\left[1-\left(\frac{p_{*}}{p_{1}}\right)^{\frac{k-1}{k}}\right]}
$$

Where $k$ is entropy index and the value is 1.4 . The $R$ is gas constant and the value is $287 \mathrm{~J} /(\mathrm{kg} \cdot \mathrm{K})$. The backpressure of grinding section is $-5 \mathrm{kpa}$. The grinding pressure is $0.76 \mathrm{Mpa}$. The pressure in formula (1) is absolute pressure. The inlet pressure $p_{1}$ of nozzle is $0.76 \mathrm{Mpa}$. The outlet pressure of nozzle is $p_{*}=5 \mathrm{kpa}+101.325 \mathrm{kpa}=0.106325 \mathrm{Mpa}$. The inlet temperatures $\mathrm{T}_{1}$ of nozzle are $290.15 \mathrm{~K}$ $\left(17^{\circ} \mathrm{C}\right)$ and $553.15 \mathrm{~K}\left(280^{\circ} \mathrm{C}\right)$, respectively.

Through the calculation from the formula (1), the $u *$ is $512 \mathrm{~m} / \mathrm{s}$ when the $T_{1}$ is $290.15 \mathrm{~K}$. The $u *$ is $707 \mathrm{~m} / \mathrm{s}$ when the $T_{1}$ is $553.15 \mathrm{~K}$. From the results, the airflow velocity at the $553.15 \mathrm{~K}$ is higher to $38 \%$ than that at the $290.15 \mathrm{~K}$.

Grinding Energy. The materials are driven to grind with a high-velocity airflow in the grinding chamber. This is a lash process. The lash velocity determines the kinetic energy of particles. In the umklapp process, only partially kinetic energy of particles is transferred to crushing energy [18], denoted by $\Delta E$. The particles has its broken energy, denoted by $W$. The kinetic energy of particle is denoted by $E$. The three relationship is $E>\Delta E \geq W$.

$$
\begin{aligned}
& E=\frac{1}{2} m u_{i}^{2} \\
& \Delta E=\frac{1}{2} m u_{i}^{2}\left(1-\xi^{2}\right) \geq W=\frac{\sigma^{2} m}{2 E \rho}
\end{aligned}
$$

The formula (4) is obtained from industrial experience for crushing the particles:

$$
u_{i} \geq u^{*}=\sigma \sqrt{\frac{1}{E \rho\left(1-\xi^{2}\right)}}
$$

Where $u_{i}$ is the particle velocity when the particles crush. $u^{*}$ is a small required velocity to crush. $\sigma$ is breaking point of the particles. $E$ is elastic modulus. $\rho$ is particle density. $m$ is particle mass. $\xi$ is recovery coefficient of particle velocity after crushing. $\xi<1$.

From the formula (3), the required kinetic energies for particles with different sizes are different. Moreover, the ultrafine particle mass is difficult to measure. The kinetic energy of a single particle is not clearly calculated. In order to compare the grinding kinetic energy at the temperature $17^{\circ} \mathrm{C}$ and $280^{\circ} \mathrm{C}$, the particle mass is assumed to unit mass. The grinding energies of particles at the nozzle outlet are compared at the temperature $17^{\circ} \mathrm{C}$ and $280^{\circ} \mathrm{C}$. The grinding energies of particles are denoted by $\mathrm{E}_{1}$ and $\mathrm{E}_{2}$ at the temperature $17^{\circ} \mathrm{C}$ and $280^{\circ} \mathrm{C}$, respectively. The outlet velocities of particles are denoted by $u_{\mathrm{i} 1}$ and $u_{\mathrm{i} 2}$ at the temperature $17^{\circ} \mathrm{C}$ and $280^{\circ} \mathrm{C}$, respectively. From the formula (2): 


$$
\frac{E_{1}}{E_{2}}=\frac{u_{i 1}^{2}}{u_{i 2}^{2}}=\frac{u_{* 1}^{2}}{u_{* 2}^{2}}
$$

Where the $u *$ is $512 \mathrm{~m} / \mathrm{s}$ when the $T_{1}$ is $290.15 \mathrm{~K}$. The $u *$ is $707 \mathrm{~m} / \mathrm{s}$ when the $T_{1}$ is $553.15 \mathrm{~K}$. From the outlet velocity of nozzles, $\mathrm{E}_{1} / \mathrm{E}_{2}=0.524$. Therefore, the grinding kinetic energy at the temperature $280^{\circ} \mathrm{C}$ is twice times than that at the temperature $17^{\circ} \mathrm{C}$.

Cut Size. The particles are grinded in the grinding chamber. The qualified particles go into classifier and go through the classifier. The particles with the diameter higher than the cut size continue to grind in the chamber. The cut size formula [19-20] is as follow:

$$
d_{c}=\frac{k}{n} \sqrt{\frac{Q}{\rho_{s}}}
$$

Where $d_{\mathrm{c}}$ is the cut size of the classier; $n$ is the rotation rate of the grading wheel; $Q$ is the gas-flow rate through the grading wheel (standard conditions); $\rho_{s}$ is the particle density; $k$ is a coefficient that is related to structure and dimension of the grading wheel, and gas viscosity, etc.

In this study, the volume of a gas flow $\left(Q_{1}\right)$ is $6.6 \mathrm{~m}^{3} / \mathrm{min}$ at the temperature $17^{\circ} \mathrm{C}$. The volume of the gas flow is $6.3 \mathrm{Nm}^{3} / \mathrm{min}$ at the standard conditions. The volume of a gas flow $\left(Q_{2}\right)$ is $9.1 \mathrm{~m}^{3} / \mathrm{min}$ at the temperature $280^{\circ} \mathrm{C}$. The volume of the gas flow is $4.54 \mathrm{Nm}^{3} / \mathrm{min}$ at the standard conditions. The classification frequencies of classifier are the same under the two temperatures. Therefore, the rotation rates of classifier are the same, and the particle density is used. The cut size of the particles is in proportion to the volume of a gas flow. The results obtained from the formula (3) is as follow:

$$
\frac{d_{c 1}}{d_{c 2}}=\sqrt{\frac{Q_{1}}{Q_{2}}}=1.18
$$

From the above result, the fine particles are obtained at the temperature $280^{\circ} \mathrm{C}$. The mean particle size at the temperature $17^{\circ} \mathrm{C}$ is 1.18 times than that at the temperature $280^{\circ} \mathrm{C}$.

\section{Numerical Simulation}

The model of the three nozzles in the chamber is designed using a software Gambit. Then, the computational fluid dynamics software (CFD) simulates and calculates the velocity fields of the nozzles and the grinding chamber. The inlet pressure of the nozzle is $0.76 \mathrm{MPa}$. The backpressure is $-5 \mathrm{KPa}$. The gas temperatures are $17^{\circ} \mathrm{C}$ and $280^{\circ} \mathrm{C}$, respectively. The axial velocity fields at the temperatures $17^{\circ} \mathrm{C}$ and $280^{\circ} \mathrm{C}$ are shown in Fig. 2 .
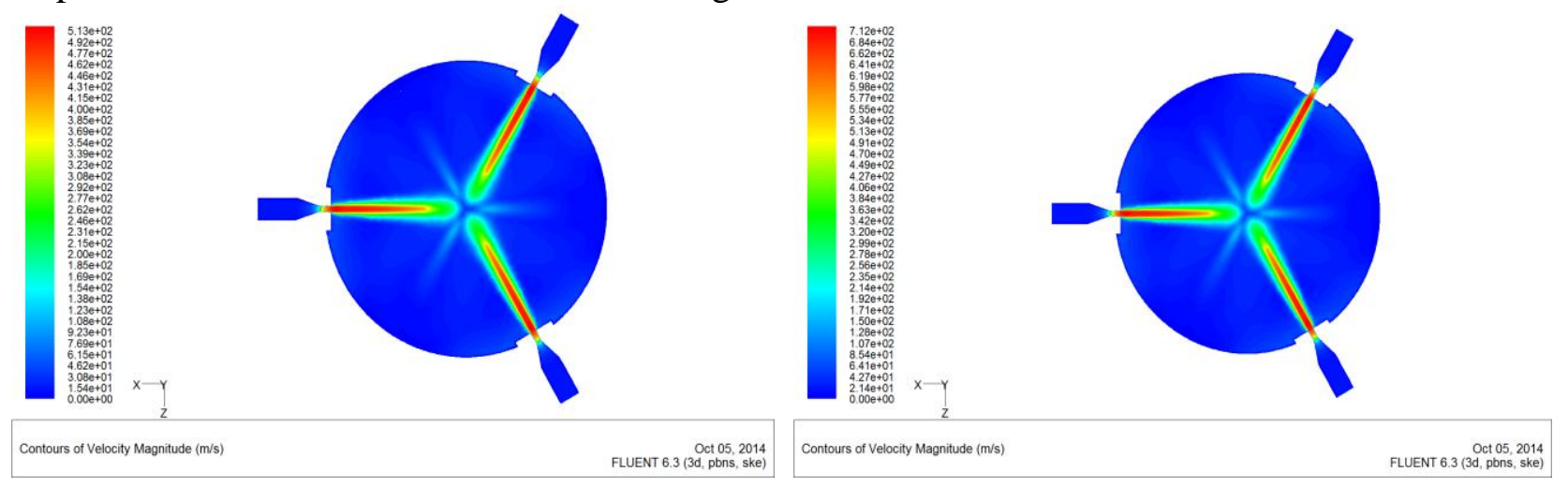

Fig.2 Axial velocity field of nozzle with $17^{\circ} \mathrm{C}$ and $280^{\circ} \mathrm{C}$

The numerical simulation shows: maximum velocity of the nozzle is higher than $513 \mathrm{~m} / \mathrm{s}$ at the temperature $17^{\circ} \mathrm{C}$. The maximum velocity of the nozzle is higher than $712 \mathrm{~m} / \mathrm{s}$ at the temperature 
$280^{\circ} \mathrm{C}$. The acceleration effect of outlet gas flow of the nozzles on particles is more obvious at the temperature $280^{\circ} \mathrm{C}$ than that at the temperature $17^{\circ} \mathrm{C}$. The gas velocity is higher than $38.79 \%$ at the temperature $280^{\circ} \mathrm{C}$ than that at the temperature $17^{\circ} \mathrm{C}$. The axial velocities of the nozzles are shown in Fig.3.

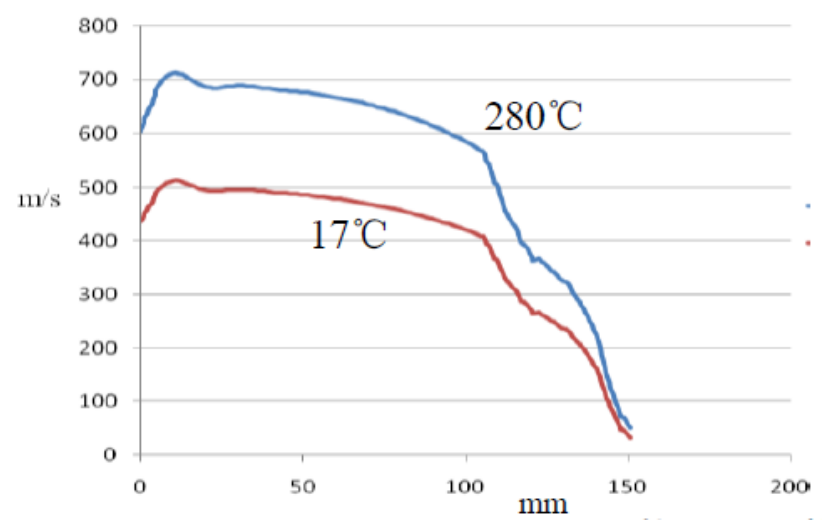

Fig. 3 The nozzle axial velocity with $17^{\circ} \mathrm{C}$ and $280^{\circ} \mathrm{C}$

It can be seen from the Fig.3, the numerical simulation results are consist with the results obtained from the theoretical arithmetic. Based on the limit theorem of the particles, the grinded particles are main brittle crushing process using a jet mill, and the completion of fatigue comminution [20]. The particles go into the chamber induced by the gas. The higher the gas velocity of the nozzle is, the larger the kinetic energy will be. Then, the particles are beneficially to grind. The transient energy of the particle increases when the particles collide with each other. The obtained size of the particle is finer at the temperature $280^{\circ} \mathrm{C}$ than that at the temperature $17^{\circ} \mathrm{C}$ using a jet mill. Additionally, the production yield increases when the temperature increases from $17^{\circ} \mathrm{C}$ to $280^{\circ} \mathrm{C}$.

\section{Experimental Results and Discussions}

The two yields of kaolin powder are obtained at the temperature $280^{\circ} \mathrm{C}$ and $17^{\circ} \mathrm{C}$. The yield of kaolin powder is $18.4 \mathrm{Kg} / \mathrm{h}$ at the temperature $17^{\circ} \mathrm{C}$. The yield of kaolin powder is $21 \mathrm{Kg} / \mathrm{h}$ at the temperature $280^{\circ} \mathrm{C}$. The particle size of kaolin is measured using a laser particle size analyzer (Beckman Kurt LS13-320 type). The mean particle size of kaolin powder is $2.401 \mu \mathrm{m}$ at the temperature $17^{\circ} \mathrm{C}$. The mean particle size of kaolin powder is $2.003 \mu \mathrm{m}$ at the temperature $280^{\circ} \mathrm{C}$.

Tab. 1 the systematic energy consumption with $17^{\circ} \mathrm{C}$ and $280^{\circ} \mathrm{C}$

\begin{tabular}{lll}
\hline & $17^{\circ} \mathrm{C}$ & $280^{\circ} \mathrm{C}$ \\
\hline Air compressor $(\mathrm{Kw})$ & 37 & 26.66 \\
Heater $(\mathrm{Kw})$ & 0 & 36 \\
Classifier $(\mathrm{Kw})$ & 4 & 4 \\
Induced fan $(\mathrm{Kw})$ & 15 & 15 \\
Total powder $(\mathrm{Kw})$ & 56 & 81.66 \\
Energy consumption/ton $(\mathrm{Kwh} / \mathrm{T})$ & 3043 & 3889 \\
\hline
\end{tabular}

The power of the air Compressor is $37 \mathrm{Kw}$. The gas flow is $6.4 \mathrm{Nm}^{3} / \mathrm{min}$ (standard condition, the gas temperature is $20^{\circ} \mathrm{C}$ and the atmospheric pressure is $101.325 \mathrm{KPa}$ ). The power of the air Compressor at the temperature $280^{\circ} \mathrm{C}$ is obtained from the standard condition. The power of the air Compressor is $26.66 \mathrm{Kw}\left(37 \mathrm{Kw} / 6.3 \mathrm{~m}^{3} / \mathrm{min} \times 4.54 \mathrm{~m}^{3} / \mathrm{min}\right)$ at the temperature $280^{\circ} \mathrm{C}$. The consumption energy of the air heater is $36 \mathrm{Kw}$ from the $17^{\circ} \mathrm{C}$ to $280^{\circ} \mathrm{C}$. The total power is obtained from an air compressor, an air heater, a classifier and an induced fan. Therefore, energy consumption of ton unit equals to the total power/yield $\times 1000$. The unit power is 1 yuan/Kwh. For the same yields of the kaolin powder unit ton, the production cost of the kaolin powder is $3043 y u a n / t o n$ at the temperature $17^{\circ} \mathrm{C}$. The production cost of the kaolin powder is 3889 yuan/ton at 
the temperature $280^{\circ} \mathrm{C}$.

The total powers are compared at the temperature $17^{\circ} \mathrm{C}$. at the temperature $280^{\circ} \mathrm{C}$, as shown in Table 1.

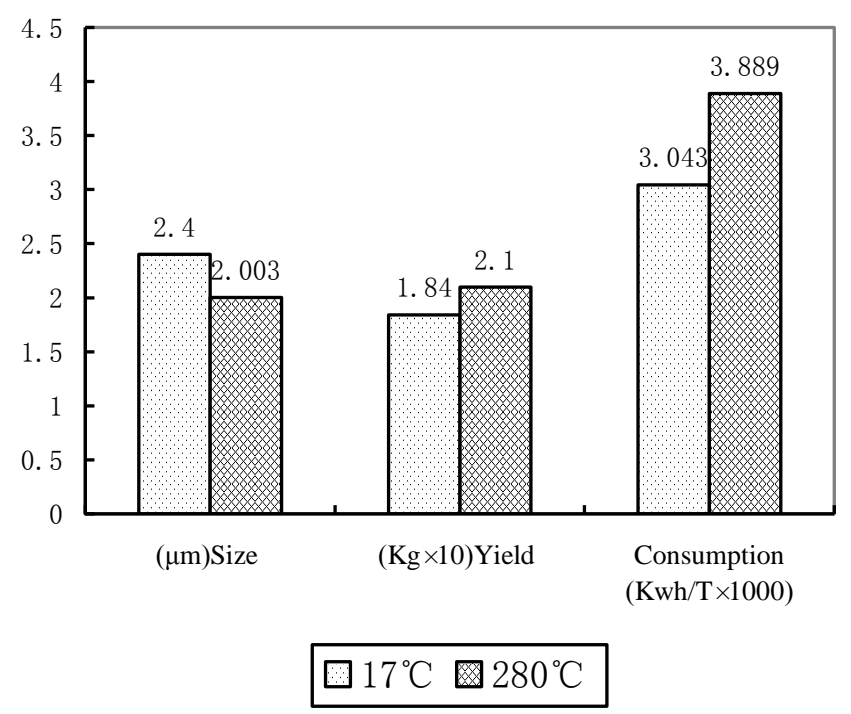

Fig.4 The particle size, fields and energy consumption with $17^{\circ} \mathrm{C}$ and $280^{\circ} \mathrm{C}$

The particle size, yields and energy consumption/ton are compared at the temperature $17^{\circ} \mathrm{C}$ and $280^{\circ} \mathrm{C}$, as shown in Fig.4. It can be seen from the Fig.4, the kaolin powder has the finer particle size at the temperature $280^{\circ} \mathrm{C}$ than that at the temperature $17^{\circ} \mathrm{C}$. Sometimes, the production yields increase with the increase in the temperature. However, the energy consumption increase to $27.8 \%$ when the temperature increase from the $17^{\circ} \mathrm{C}$ to $280^{\circ} \mathrm{C}$. These results are consisting with the results obtained from the theoretical arithmetic and numerical simulation.

\section{Conclusions}

(1) The kaolin powder is obtained using an LNJH-60A type fluidized-bed jet mill (Designed by Mianyang, Liuneng, Powder Equipment, Co., Ltd.). The qualified kaolin powder has the narrow particle size distribution, and no pollution in the grinding process. The kaolin powders meet the demands for making the papermaking and the painting.

(2) Two results are compared at the temperature $17^{\circ} \mathrm{C}$ and $280^{\circ} \mathrm{C}$. The outlet velocity is higher $38 \%$ at the temperature $280^{\circ} \mathrm{C}$ than that at the temperature $17^{\circ} \mathrm{C}$. The yield increase to $14 \%$ when the temperature increase from the $17^{\circ} \mathrm{C}$ to $280^{\circ} \mathrm{C}$. The total energy consumption is higher $28 \%$ at the temperature $280^{\circ} \mathrm{C}$ than that at the temperature $17^{\circ} \mathrm{C}$.

\section{Acknowledgement}

This research was financially supported by the Doctor's Fund of Southwest University of Science and Technology (no. 14ZX7127) and Education Department of Sichuan Province (no. 13ZB0174).

\section{References}

[1] J.A.F. Gamelasa, E. Ferrazb, F. Rocha. An insight into the surface properties of calcined kaolinitic clays: The grinding effect [J]. Colloids and Surfaces A: Physicochem. Eng. Aspects 455 (2014) 49-57.

[2] J. Bai, Fabrication and properties of porous mullite ceramics from calcined carbonaceous kaolin and $\alpha-\mathrm{Al} 2 \mathrm{O} 3$, Ceram [J]. Int. 36 (2010) 673-678. 
[3] P. He, D. Jia, Low-temperature sintered pollucite ceramic from geopolymer precursor using synthetic metakaolin [J]. J. Mater. Sci. 48 (2013) 1812-1818.

[4] C. Kohl, R. Berube, Kaolin-based systems for increasing gpaperopacity, Wochen-blatt fur Papierfabrikation [J]. 132 (2004) 1400-1405.

[5] J. Shen, Z. Song, X. Qian, W. Liu, Modification of papermaking grade fillers: a brief review [J]. Bioresources, 4 (2009) 1190-1209.

[6] Chen Wenrui. Development and application of ceramic super kaolin in China [J]. Chinese ceramics, 2008,11:59-62.

[7] Liu Jun, He Beihai, Zhao Lihong. Experimental study of paper coating kaolin ultrafine classification [J]. Paper Science \& Technology, 2009,02:45-50+54.

[8] Li Qicheng, Duan Xiaolin, Hu Yurong. The experimental disquisition about super fine classification to kaolin [J]. University of South China (Science and Technology), 2006,03:67-69.

[9] Deng Shaoxia, Xue Qinhu. Application of less burned super fine powder of coal measures kaolin to refractory pouring material [J]. Coal mine engineering, 2010,05:96-99.

[10] Zou Zhengguang, He Zengxian, Yu Shijin. Meticulous treatment of kaolin and application in new materials [J]. Journal of Guilin Institute of Technology, 2004,02:205-210.

[11] Aleksandra Mitrović, Miodrag Zdujić. Preparation of pozzolanic addition by mechanical treatment of kaolin clay [J]. International Journal of Mineral Processing 132 (2014) 59-66.

[12] Dellisanti, F., Valde, G., 2012. The role of microstrain on the thermostructural behaviour of industrial kaolin deformed by ball milling at low mechanical load. Int. J. Miner. Process. 102-103, 69-77.

[13] Cai Jian. The present situation and development trend of kaolin processing technology in China [J]. Non-Metallic Mines, 2005,S1: 9-11.

[14] Ding Hao, Li Huang, Jiu Yaohui, Sun Shouli. Study on the stirring mill grinding calcined coal kaolin [J]. Building Materials Geological, 1996,06:35-37.

[15] Zhang Mingxing, Chen Haiyan, Yan Cuiping, Lin Longyuan. Study on process parameters of hard kaolin by mechanical energy mill [J]. Metal Mine, 2012,03:123-126.

[16] Chen Haiyan. Research and application of fluidized bed jet mill technology [D]. Chengdu: Sichuan University, 2007.

[17] Jin Zhenzhong, Wang Hongbin, Ge Xiaoling, Wu Chunbo. Application of hot compressed air in jet grinding mill and the design of feeder injector [J]. Industrial Minerals \& Processing, 2006,09:18-21, 34.

[18] Lu Shouci. Powder Technology Handbook [M]. Beijing: Chemical Industry Press, 2007.

[19] R.Nied. Fine classification with vaned rotor: at the outer edge of the vanes or in the interior vane free area [J]. Int.J.Miner.Process,2004,74:137-145.

[20] A.Bauder,F.muller, R. Polke. Investigations concerning the separation mechanism in deflector wheel classifiers [J]. Int.J.Miner.Proeess, 2004,74:147-154.

[21] Li Guokang, Yang Yunchuan, Zhu Yingjie. Analysis of the effect of fluidized bed jet mill [J]. Journal of Shenyang University of Technology, 2003, 22(2): 69-72. 